\title{
Recognition and Assessment of Geomorphosites in Malta at the Il-Majjistral Nature and History Park
}

\author{
Paola Coratza • Viola Maria Bruschi • \\ Daniela Piacentini $\cdot$ Darren Saliba $\cdot$ Mauro Soldati
}

Received: 21 April 2010 / Accepted: 15 March 2011 /Published online: 10 April 2011

(C) Springer-Verlag 2011

\begin{abstract}
The Il-Majjistral Nature and History Park, located on the northwestern coast of the Island of Malta, is a protected area with natural, cultural and tourist interests. The Park, which was registered in 2008 , is characterised by a landscape dominated by limestone and clay. Geomorphological features are highly controlled by the presence of faults and rock masses characterised by different physical and mechanical properties. Coastal cliffs, bays and sandy beaches are the most outstanding geomorphological features of the Park, creating a breathtaking landscape which is an attraction for a number of visitors. In the framework of an international research project, a study for the identification, selection and enhancement of the rich geomorphological heritage of the area has been carried out. In particular, a recognition and a quantitative assessment of geomorphosites on the basis of two different methodologies has been developed, and the results have been compared to establish the reliability of the methodologies. The results represent the first step and the necessary basic knowledge for possible enhancement of geomorphosites in Malta and the promotion of tourism activities at the Il-Majjistral Nature
\end{abstract}

P. Coratza $(\bowtie) \cdot$ D. Piacentini $\cdot$ M. Soldati

Department of Earth Sciences,

University of Modena and Reggio Emilia,

Largo S. Eufemia 19,

41121 Modena, Italy

e-mail: paola.coratza@unimore.it

\section{M. Bruschi}

Department of Earth Sciences and Condensed Matter Physics, University of Cantabria,

Avda. De Los Castros s/n,

39005 Santander, Spain

D. Saliba

The Heritage Parks Federation,

Melita Street 133,

Valletta, Malta and History Park through the auspices of environmental agencies.

Keywords Geomorphosite recognition · Quantitative geomorphosite assessment $\cdot$ Malta

\section{Introduction}

The Island of Malta is situated in the Mediterranean Sea, about $90 \mathrm{~km}$ south of Sicily and $290 \mathrm{~km}$ north-east of Tunisia. Malta is an important tourist area that is especially sought for its cultural and natural heritage and outdoor activities, such as hiking, trekking and country-walking (Magri et al. 2007; Soldati et al. 2008a). Although the Island is intensively built up, it still conserves remarkable geomorphological features. These are mostly found along the coastal areas, where the aesthetic qualities of the natural landscape are highly maintained (Soldati et al. 2008b).

The Maltese economy is mainly supported by tourism, which has steadily increased since the late 1970s, mainly in the coastal areas. However, the positive contribution of tourism to the national economy is accompanied by some negative implications in the use of coastal resources (Trumbic 2004).

The Il-Majjistral Nature and History Park, Malta's first National Park, is located in the north-west of the Island of Malta and includes a coastal stretch of about $7 \mathrm{~km}$ in length (Fig. 1) covering the area from Anchor Bay to Golden Bay. The Park includes elements of natural and cultural interest and is, thereby, a valuable tourism product. Within this area it is possible to find both areas of rural and military heritage, unique habitats for flora, natural caves and outstanding coastal cliffs. These create a landscape which attracts many visitors, both local and foreign. The coastal zone hosts a number of important habitats and represents an 


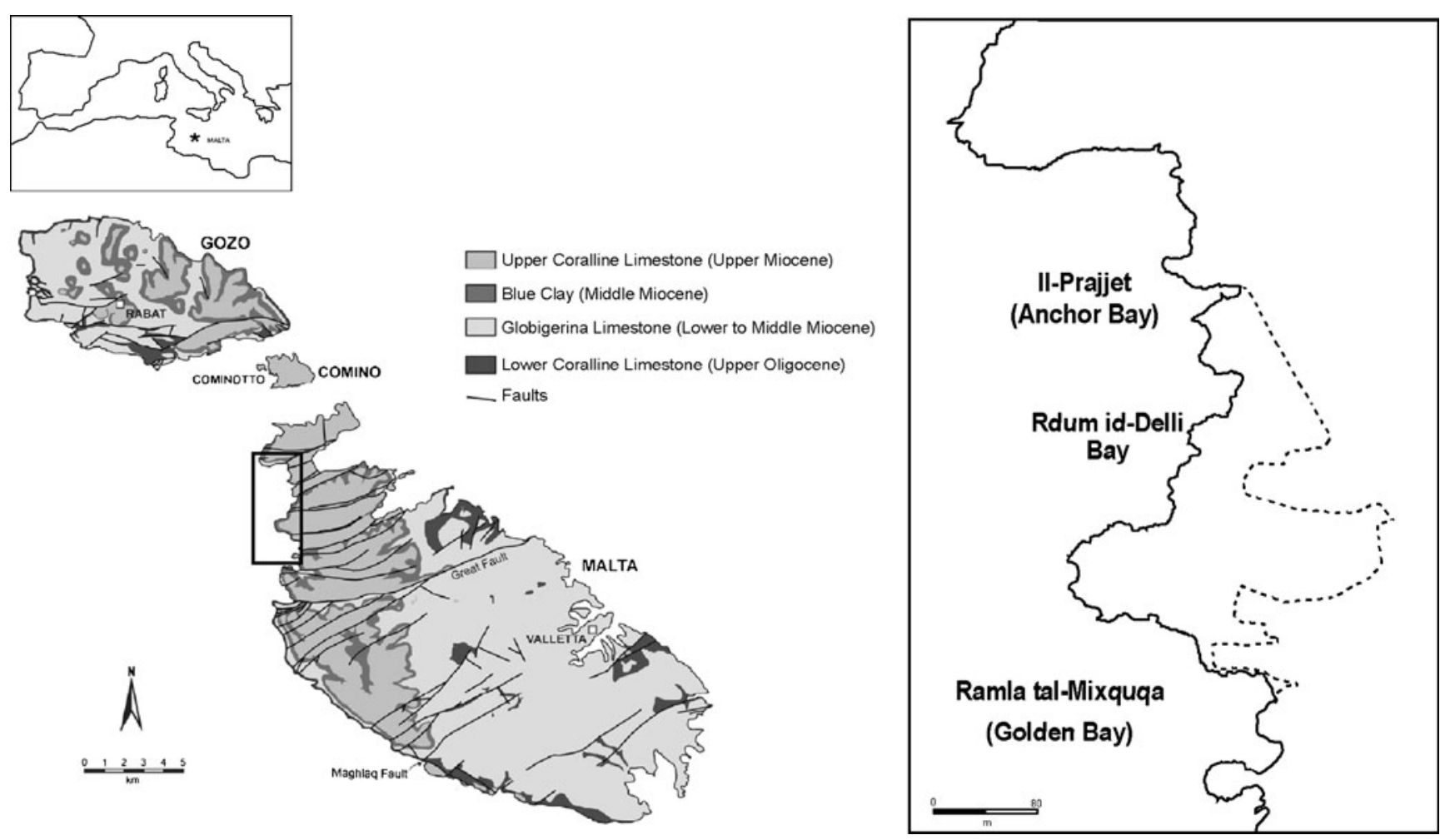

Fig. 1 Location and geological setting of the Il-Majjistral Nature and History Park. Left Geological setting of the Maltese Island (adapted from Geological Map of the Maltese Islands 1993). Right Dashed line delimits the park boundary

area of ecological importance, which now form part of the list of Natura 2000 sites of international importance. The rural, vernacular and military heritage of the area are intimately linked to the geographical landscape in which they are situated and form an important cultural landscape. These features include cart-ruts, long rubble walls (dry stone walls), farmhouses, small beehives, tombs dating to the Classical period, natural caves and numerous corbelled stone huts. Documentation on the cultural and biological aspects of the park has been extensively studied, but there has unfortunately been no specific research focussing on the identification of geomorphological features in the area; such information could be useful for tourism and educational purposes.

Based on these premises, a research programme for the recognition and assessment of geomorphosites at Il-Majjistral Nature and History Park has been developed. In particular, in order to better design the enhancement activities in the study area, the assessment of the site's quality has been carried out within the Park. Two different quantitative methods (quantitative parametric and semi-quantitative) have been applied to the selected geomorphosites, and the results obtained have been compared to establish the reliability of the methodologies. Both of the methods applied have been developed and tested in previous studies (Bruschi and Cendrero 2005; Coratza and Giusti 2005; Bruschi 2007) and in different geological and geomorphological contexts.

\section{Geological and Geomorphological Features of the Il-Majjistral Nature and History Park}

In terms of geological aspects, the main lithological outcrops belong primarily to two distinct geological formations, namely, Blue Clay and Upper Coralline Limestone. The overposition of limestones on the clays has a direct control upon the surface topography and landform evolution. These formations generally lie almost horizontally and are dissected by several sub-vertical faults and a series of joints (Geological Map of the Maltese Islands 1993) (Fig. 1) which also influence geomorphological processes.

The Blue Clay Formation (Middle Miocene) was deposited in a deep-sea depositional setting and is made up of fine-grained sediments with a large component of organic material derived from planktonic organisms. It consists of sequences of alternating pale-grey and dark-grey banded marls, with lighter bands containing a higher proportion of carbonate (Pedley et al. 1978). This formation, whose deposition corresponds to the major tectonic phase of the Siculo-Maghrebid chain uplift, does not present more than 30\% carbonate material (Murray 1890), which is usually made up of fossils restricted to microfauna or crushed specimens of macrofauna. This lithology forms gentle slopes that are generally covered by soil and vegetation and affected by mass movements, in particular earth flows and earth slides. 
The Upper Coralline Limestone Formation (Upper Miocene) comprises shallow marine sediments which have characteristics derived from several different marine or intertidal environments and contain different types of corals and coralline algae. This formation displays a wide range of lateral and vertical facies variation (Pedley et al. 1978), and the lithology generally forms steep cliffs characterised by a sparse vegetation cover (Pedley et al. 2002) and welldeveloped karst topography (Pedley et al. 1976). These geological features provide favourable conditions for percolation and underground storage of rainwater (House et al. 1961). In particular, the presence of bedding planes and joints is very important in controlling the underground movement of water. The Island's weather conditions, which are characterised by heavy and localised rain showers, coupled with rapid surface runoff are factors that limit the availability of underground water storage.

The overlapping of the Upper Coralline Limestone on the Blue Clay also favours the onset of diffuse rock spreading phenomena (Magri et al. 2007), due to the different mechanical properties of the two formations, which affect most of the coastal cliffs of the Park.

From a geomorphological point of view, the relief is predominantly controlled by geological structure and, in particular, by faults oriented ESE-WSW, which determined the development of a horst and graben morphology (Alexander 1988).

Landforms in the study area can be related to different morphogenetic factors and processes.

Structural landforms include platforms and scarps remodelled by coastal erosion and/or gravitational processes occurring mainly within the Upper Coralline Limestone Formation. The edges of the structural platforms are very often characterised by faults and fractures, widened by chemical weathering and rock spreading. Fissures play an important role in the instability of the limestone cap rock, favouring processes of detachment and the subsequent displacement of the rock boulders.

In general, the northwestern coastal region is characterised by gravitational processes which have induced the occurrence of diverse types of landslides. Deep-seated gravitational slope deformations (especially lateral spreading), due to the different mechanical behaviour and diverse hydrogeological conditions of the outcropping lithology, are representative of the main types of landslides occurring on the Island (Magri et al. 2007). Rock falls, block slides and earth flows are sometimes closely associated to these phenomena (Fig. 2: ID 6, 9, 10).

High and steep cliffs remodelled by the mechanical action of waves (Paskoff 1985) and two sandy beaches represent the main coastal landforms of the research area. Marine erosion plays an important role in shaping the landscape, producing inlets and bays with small pocket beaches at the head of the bays.

In terms of fluvial landforms, both depositional and erosional landforms can be observed. V-shaped small dry valleys in the Upper Coralline Limestone are of particular importance. These dry valleys, currently converted to agricultural land or terraced fields, are relicts of former pluvial conditions and extensive groundwater sapping. Other fluvial landforms are large valley beds and alluvial/colluvial cones consisting of Quaternary sediments transported and deposited through the action of water as well as gravitational processes. Examples of badland topography occur in the steep Blue Clay slopes which, being bare of vegetation cover, are exposed to the action of water (Fig. 2: ID 1).
Fig. 2 Examples of geomorphosites in the Park area related to surface erosion and slope instability processes: 1 badland topography in a steep Blue Clay slope, 6, 9, 10 areas affected by rock spreading and related landslides accumulations (photographs 6, 9 and 10 were provided courtesy of Ten. Col. M. Marchetti). Numbers correspond to the geomorphosites' identification (ID)
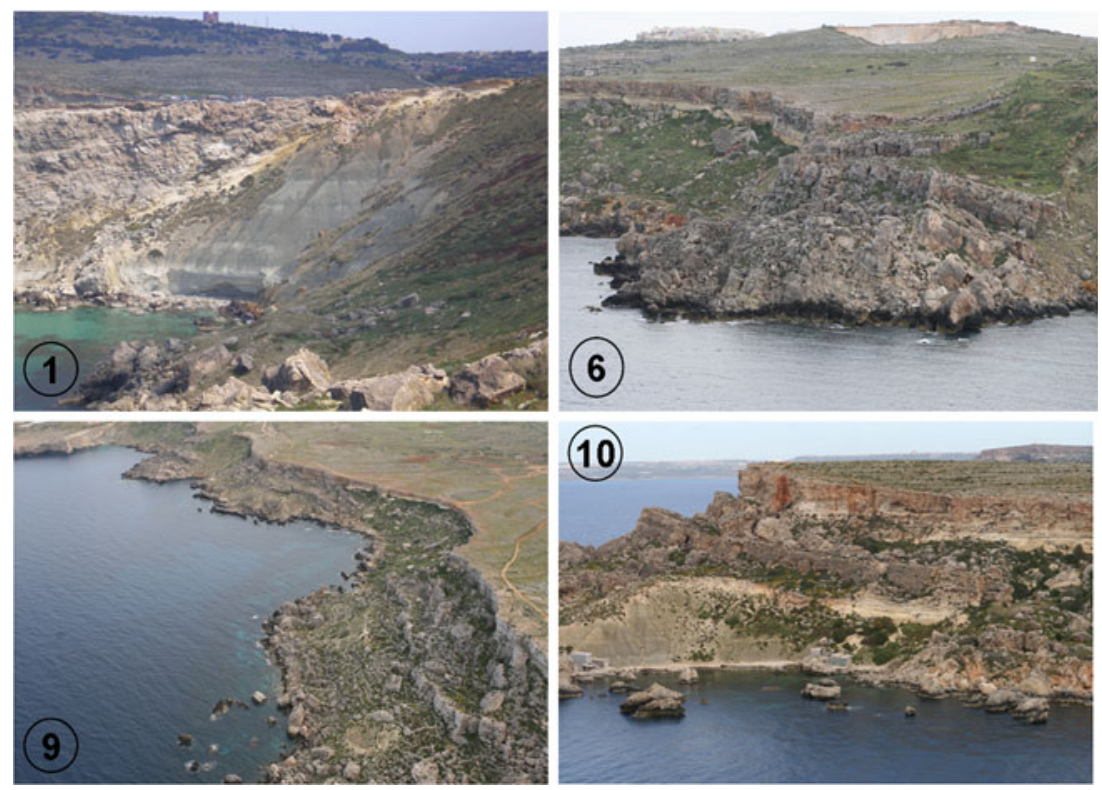
As Coralline Limestone terrain is very sensible to dissolution due to its content of calcium carbonate and high fissure density (Paskoff and Sanlaville 1978), karstification is well developed in the area. The most widespread karstic feature is the surface topography of plateaus characterised by highly irregular and rugged shapes, resulting from dissolution processes (Fig. 3). Two dissolution subsidence landforms within the Upper Coralline Limestone have also been recognised in the area (Fig. 4: ID 2, 5).

Several terrains in the Park have been significantly influenced through time by human activity due to exploitation for agricultural and tourism purposes. In particular, both at both coastal and inland locations, slopes have been remodelled into terraced fields retained by rubble walls (dry stone walls) and used as agricultural land (Cyffka and Bock 2008). Archaeological features include rock-cart ruts, small scale erosional landforms incised into the bedrock of uncertain origin and age (Mottershead et al. 2008), numerous corbel huts and notable remains of British military architecture.

\section{Geomorphosite Recognition and Selection}

The research on geomorphosites at the Il-Majjistral Nature and History Park started by examining existing thematic maps and scientific papers on the geology and geomorphology of the Park, as well as tourist maps and guidebooks. Field campaigns resulted in the identification and classification of the most significant geomorphosites and the verification of the collected bibliographical data. The above-mentioned parameters were also observed in detail.

According to Reynard (2004) "geosites are portions of the geosphere that present a particular importance for the comprehension of the Earth history". More precisely, geomorphosites are defined as geomorphological objects that have acquired scientific, cultural/historical, aesthetic

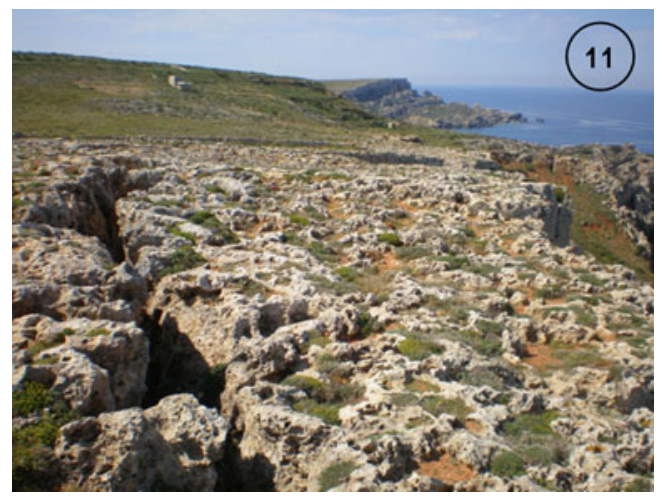

Fig. 3 Example of dissolution surface on the study area. Fissures due to lateral sprading area clearly shown. Number correspond to the geomorphosites' identification (ID) and/or socio-economic value due to human perception or exploitation (Panizza 2001). Therefore, we have tried to select and evaluate those elements of the landscape which, in addition to being spectacular, can make a significant contribution to the understanding of the geomorphological history of the region and also be of interest to tourists. Indeed, the priority criteria for the choice of sites have taken various factors into account, such as those related to the social role attributed by communities outside the field of Earth Science. The integration of these factors with those usually recognised by geoscientists can contribute towards the qualification of geological objects as having heritage value in a socio-cultural perspective (Pena dos Reis and Henriques 2009). In particular, the identification and selection process concentrates on the following range of values: scientific value, additional value and use value (Table 1) (cf. Panizza and Piacente 1993; Reynard et al. 2007; Pereira et al. 2007).

Our field research identified 13 geomorphosites (Fig. 5), including landslides (lateral spreads, block slides and rock falls), dissolution subsidence structures, areas characterised by dissolution surfaces, dry valleys and badlands.

The most significant landforms within the Park are landslides located along the coast and favoured by the overposition of the Upper Coralline Limestone on the Blue Clay (Fig. 2). These landforms have been selected especially because they make up exemplary cases and are the result of key processes that provide a comprehensive understanding of the geomorphological evolution of rocky-coastal areas.

Of particular interest is the badland landscape on the Blue Clays slopes close to Rdum id-Delli Bay, selected as a geomorphosite for its educational and aesthetic values.

Some epikarst morphologies can be considered as geomorphosites for their educational value and for their rarity. Worthy of note is the dissolution subsidence landform at Rdum id-Delli that affects the Upper Coralline Limestone; it was formed as a result of dissolution processes, accompanied by ground subsidence (Magri 2009). This type of landform, although less evident, is found inland from Rdum id-Delli, where a wide depression is presently used as agricultural land. Other karstic landforms include the surface topography of limestone plateaus and ridges characterised by irregular and rough terrain where a garrigue vegetation community has developed (Fig. 3).

Dry valleys are another type of geomorphosite identified in the area; three sites have been selected, two in the northern part of the park and the third in the south. They correspond to V-shaped deep small valleys that developed in relatively wetter climate conditions and are occupied nowadays by agricultural land and terraced fields. These landforms have been selected especially for their scientific value, as witness to former pluvial conditions. 
Fig. 4 Examples of dissolution structures present in the Park area. 2 Very large dissolution structures. Dashed line delineates the external limit of the sinkhole. $\mathbf{5}$ Dissolution structure located in the coastal area (Photograph 5 is provided courtesy of Ten. Col. M. Marchetti). Numbers correspond to geomorphosites' ID
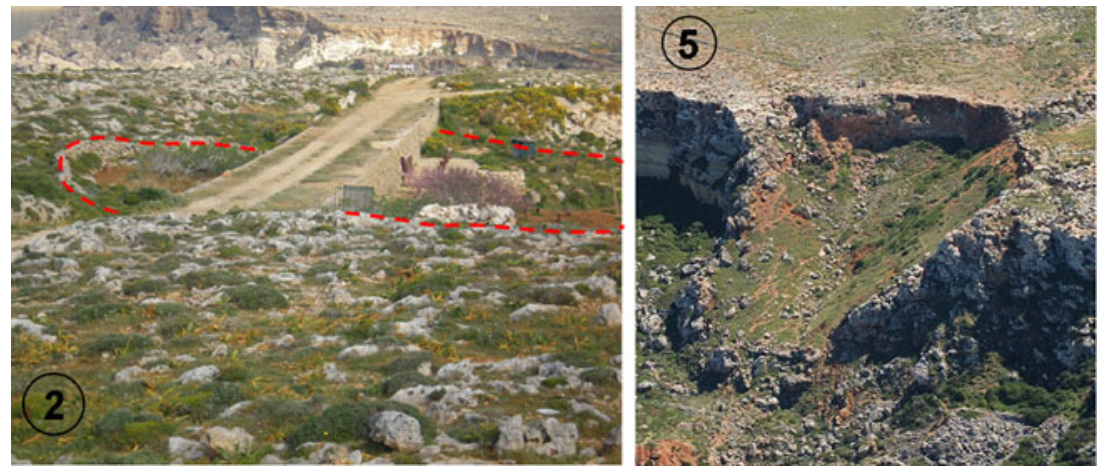

\section{Geomorphosite Assessment}

The Issue of Subjectivity

Numerous methods for the quantitative assessment of landforms are described in the literature. The earliest of these go back to the 1970s and were generally developed by scholars from English-speaking countries, in particular from the USA. Worthy of note are the assessment procedures by Linton (1968), Fines (1968) and Leopold (1969) which, nevertheless, present considerable limits because they are either too subjective or based on an unnatural subdivision of geomorphological assets. During the last decades, several attempts have been made to evaluate the quality of geomorphological heritage in various contexts: environmental impact assessment and territorial planning (Barba et al. 1997; Rivas et al. 1997; Coratza and Giusti 2005; Bruschi and Cendrero

Table 1 Values and corresponding criteria used for the identification and selection of geomorphosites

\begin{tabular}{ll}
\hline Value & Criteria \\
\hline Scientific value & Palaeogeomorphological model \\
& Rareness \\
& Representativeness \\
& Integrity \\
Additional value & \\
Ecological value & Ecological support role \\
Aesthetic value & Protected site \\
& Panoramic quality \\
& Colour diversity \\
Cultural value & Spectacularity \\
& Naturalness \\
Use value & Religious importance \\
& Historical importance \\
& Artistic importance \\
& Accessibility \\
& Visibility \\
& Services \\
& Importance for education \\
\hline
\end{tabular}

2005); inventories of natural heritage sites (Serrano and Gonzalez-Trueba 2005; Reynard et al. 2007); tourist promotion (Pralong 2005); management of nature parks (Pereira et al. 2007; Zouros 2007).

The scientific quality of an asset is a purely indicative numerical quantity which can be subject to variations determined by the subjectivity of the operators and the general characteristics of the area under examination. However, despite these limitations, there has been a real attempt to

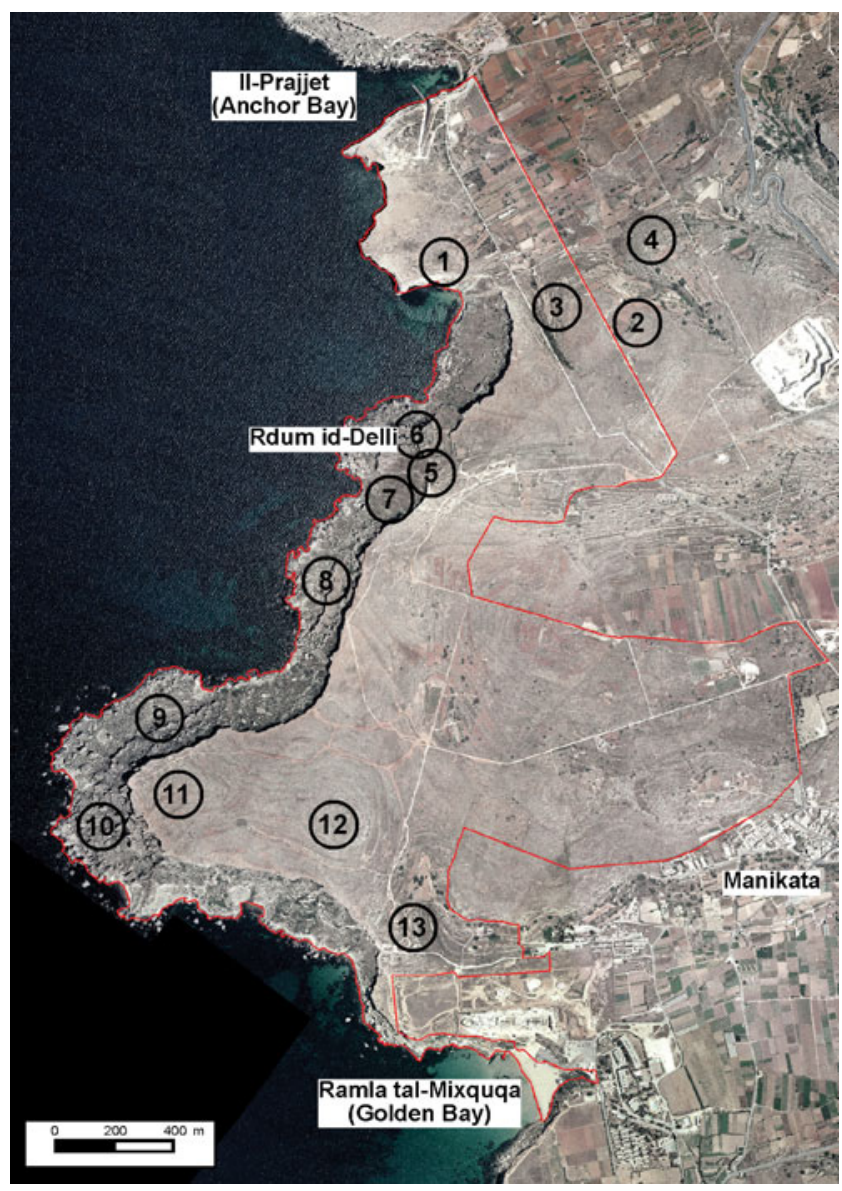

Fig. 5 Sketch of Il-Majjistral Nature and History Park and indication of the selected geomorphosites. The numbers correspond to the ID of geomorphosites (see Tables 2, 3, 4, 5), and the red line delimits the park boundary 
express each geomorphological asset's scientific importance numerically so as to be able to compare them (Reynard 2009).

In general, it must be said that all methodologies inevitably imply a degree of subjectivity since the intrinsic value of these environmental elements cannot really be measured. In order to reduce subjectivity, numerous assessment methods, each based on several assessment criteria, have been developed. Three of the criteria are recurrent in all methods, namely, rarity, representativeness and integrity; others, such as ecological value, paleogeographic importance, educational value, among others, are dependent on the context of the assessment and on the aims of the research (Reynard et al. 2007). Notwithstanding, even in these methods, it would seem impossible to avoid subjectivity, as the allocation of value and weights for most criteria again depends on the opinion and the experience of the assessor.

\section{Application of the Quantitative Parametric Method}

On the basis of previous works (Bruschi and Cendrero 2005; Bruschi 2007; Bruschi et al. 2011), we have applied a quantitative parametric method based on three sets of parameters to assess the value of the geomorphosites identified in the study area:

- intrinsic quality (directly related to scientific aspects),

- potential for use (as a cultural, educational or tourist resource),

- potential threats and protection needs.
Bruschi (2007) has identified 19 numerical indices for each set of parameters; these are based on the results of a survey among experts in Earth Sciences and can be considered to be necessary for the assessment of geomorphosite value. Our approach consisted of first summing the values assigned by experts and then normalising these to a $0-1$ scale value. The relative weight (W) of each parameter was then calculated, and these were used for the geomorphosite assessment. Each selected geomorphosite was assessed assigning a value ranging from 1 to 3 to each parameter considered. The results are shown in Table 2.

The quantification of the value of each set of parameters enables the geomorphosite quality $\left(\mathrm{Q}_{\mathrm{G}}\right)$ to be defined through the following expression:

$\mathbf{Q}_{\mathrm{G}}=(\mathrm{IQ}+\mathrm{P}+\mathrm{C}) / 3$

where:

$\mathrm{Q}_{\mathrm{G}} \quad=$ geomorphosite quality $(0-1)$,

IQ = intrinsic quality of the site (1-3),

$\mathrm{P} \quad=$ potential for use of site (1-3) and

$\mathrm{C}=$ Potential threats and protection needs $(1-3)$.

The value of each set of parameters has been defined on the basis of the following expressions:

$\mathbf{I Q}=\mathrm{W}_{\mathrm{EP}} \mathrm{EP}+\mathrm{W}_{\mathrm{R}} \mathrm{R}+\mathrm{W}_{\mathrm{VE}} \mathrm{VE}+\mathrm{W}_{\mathrm{P}} \mathrm{P}+\mathrm{W}_{\mathrm{K}} \mathrm{K}$

where

Table 2 Parameter assessment for each site on a scale of 1-3

\begin{tabular}{|c|c|c|c|c|c|c|c|c|c|c|c|c|c|c|c|c|c|c|c|c|}
\hline ID & Geomorphosite & EP & $\mathrm{R}$ & $\mathrm{C}$ & EI & $\mathrm{N}$ & IP & $\mathrm{O}$ & $\mathrm{F}$ & VE & IC & $\operatorname{Pr}$ & $\mathrm{H}$ & IR & $\mathrm{AC}$ & ENP & $\mathrm{K}$ & SA & $\mathrm{T}$ & $\mathrm{E}$ \\
\hline 1 & $\begin{array}{l}\text { Badland topography } \\
\text { in Blue Clay slopes }\end{array}$ & 3 & 3 & 3 & 3 & 3 & 1 & 2 & 1 & 2 & 2 & 2 & 2 & 3 & 1 & 3 & 3 & 2 & 1 & 2 \\
\hline 2 & $\begin{array}{l}\text { Solution subsidence } \\
\text { structure }\end{array}$ & 2 & 3 & 1 & 2 & 3 & 1 & 2 & 1 & 1 & 1 & 1 & 3 & 3 & 3 & 2 & 1 & 1 & 2 & 2 \\
\hline 3 & Dry valley & 2 & 2 & 2 & 2 & 3 & 1 & 3 & 1 & 2 & 1 & 1 & 1 & 3 & 3 & 3 & 2 & 2 & 2 & 2 \\
\hline 4 & Dry valley & 2 & 2 & 2 & 2 & 3 & 1 & 3 & 1 & 2 & 1 & 1 & 1 & 3 & 1 & 2 & 1 & 1 & 2 & 2 \\
\hline 5 & $\begin{array}{l}\text { Solution subsidence } \\
\text { structure }\end{array}$ & 1 & 3 & 1 & 2 & 3 & 1 & 3 & 2 & 3 & 2 & 3 & 2 & 3 & 1 & 3 & 2 & 2 & 2 & 2 \\
\hline 6 & $\begin{array}{l}\text { Area affected by rock } \\
\text { spreading }\end{array}$ & 3 & 1 & 3 & 3 & 3 & 2 & 2 & 1 & 3 & 2 & 3 & 2 & 3 & 1 & 3 & 3 & 2 & 2 & 2 \\
\hline 7 & $\begin{array}{l}\text { Badland topography } \\
\text { in Blue Clay slopes }\end{array}$ & 3 & 3 & 3 & 3 & 3 & 1 & 2 & 1 & 2 & 2 & 2 & 2 & 3 & 1 & 3 & 3 & 2 & 1 & 2 \\
\hline 8 & $\begin{array}{l}\text { Area affected by rock } \\
\text { spreading }\end{array}$ & 3 & 1 & 3 & 3 & 3 & 2 & 2 & 1 & 3 & 2 & 3 & 2 & 3 & 2 & 3 & 3 & 2 & 2 & 2 \\
\hline 9 & $\begin{array}{l}\text { Area affected by rock } \\
\text { spreading }\end{array}$ & 3 & 1 & 3 & 3 & 3 & 2 & 2 & 1 & 3 & 2 & 3 & 2 & 3 & 1 & 3 & 3 & 2 & 2 & 2 \\
\hline 10 & $\begin{array}{l}\text { Area affected by rock } \\
\text { spreading }\end{array}$ & 3 & 1 & 3 & 3 & 3 & 2 & 2 & 1 & 3 & 1 & 3 & 2 & 3 & 1 & 3 & 3 & 2 & 2 & 2 \\
\hline 11 & $\begin{array}{l}\text { Karst landform } \\
\text { (limestone pavements) }\end{array}$ & 3 & 3 & 2 & 1 & 3 & 2 & 3 & 1 & 1 & 1 & 2 & 2 & 3 & 2 & 3 & 2 & 2 & 2 & 2 \\
\hline 12 & $\begin{array}{l}\text { Karst landform } \\
\text { (limestone pavements) }\end{array}$ & 3 & 3 & 2 & 1 & 3 & 2 & 3 & 1 & 1 & 1 & 2 & 2 & 3 & 1 & 3 & 2 & 2 & 2 & 2 \\
\hline 13 & Dry valley & 2 & 2 & 2 & 1 & 2 & 1 & 3 & 1 & 2 & 3 & 1 & 1 & 3 & 1 & 3 & 2 & 2 & 2 & 2 \\
\hline
\end{tabular}

For definition of the parameters, refer to the expression reported in the text 


$$
\begin{array}{ll}
\text { IQ } & =\text { intrinsic quality of site, } \\
\mathrm{EP} & =\text { good example of process }(1-3), \\
\mathrm{R} & =\text { abundance/rarity }(1-3), \\
\mathrm{VE} & =\text { diversity of elements }(1-3), \\
\mathrm{Pr} & =\text { other processes associated }(1-3), \\
\mathrm{K} & =\text { degree of knowledge }(1-3), \\
\mathrm{W}_{\mathrm{EP} \text { etc. }} & =\text { weight of parameters; } \\
& \\
\mathbf{P}=\mathrm{W}_{\mathrm{IP}} \mathrm{IP} & +\mathrm{W}_{\mathrm{O}} \mathrm{O}+\mathrm{W}_{\mathrm{IC}} \mathrm{IC}+\mathrm{W}_{\mathrm{AC}} \mathrm{AC}+\mathrm{W}_{\mathrm{SA}} \mathrm{SA} \\
& +\mathrm{W}_{\mathrm{E}} \mathrm{E}+\mathrm{W}_{\mathrm{EI}} \mathrm{EI}
\end{array}
$$

where

$\begin{array}{ll}\text { P } & \text { = potential for use of site, } \\ \text { IP } & =\text { landscape interest }(1-3), \\ \text { O } & \text { Observation conditions (1-3), } \\ \text { IC } & \text { Cultural interest (1-3), } \\ \text { AC } & \text { Accessibility (1-3), } \\ \text { SA } & \text { Environmental services (1-3), } \\ \text { E } & \text { Economic significance (1-3). } \\ \text { EI } & \text { Educational interest (1-3). } \\ \text { W }_{\text {IP etc. }} & \text { Weight of parameters; }\end{array}$

$$
\begin{aligned}
\mathbf{C}= & \mathrm{W}_{\mathrm{N}} \mathrm{N}+\mathrm{W}_{\mathrm{F}} \mathrm{F}+\mathrm{W}_{\mathrm{H}} \mathrm{H}+\mathrm{W}_{\mathrm{IR}} \mathrm{IR}+\mathrm{W}_{\mathrm{ENP}} \mathrm{ENP}+\mathrm{W}_{\mathrm{T}} \mathrm{T} \\
& +\mathrm{W}_{\mathrm{C}} \mathrm{C}
\end{aligned}
$$

where

$$
\begin{array}{ll}
\text { C } & =\text { potential threats and protection needs, } \\
\mathrm{N} & =\text { naturalness }(1-3), \\
\mathrm{F} & =\text { fragility }(1-3), \\
\mathrm{H} & =\text { related with human issues }(1-3), \\
\mathrm{IR} & =\text { recreational interest }(1-3), \\
\mathrm{ENP} & =\text { natural protected area }(1-3), \\
\mathrm{T} & =\text { size }(1-3), \\
\mathrm{C} & =\text { degree of preservation }(1-3), \\
\mathrm{W}_{\mathrm{N} \text { etc. }} & =\text { weight of parameters. }
\end{array}
$$

Table 3 shows the quality of the selected geomorphosites $\left(\mathrm{Q}_{\mathrm{G}}\right)$. The geomorphosites with the highest values $(0.777-$ 0.790 ) correspond to areas affected by rock spreading (ID 8, ID 6 and ID 9) which, in particular, show high values of Intrinsic quality (IQ) and Potential for use (P). Actually, rock spreading geomorphosites, due to their representativeness and exemplariness, may be easily and effectively exploited for scientific and educational purposes.

\section{Application of the Semi-quantitative Method}

The second assessment procedure which was applied is based on the methodology elaborated by Coratza and Giusti

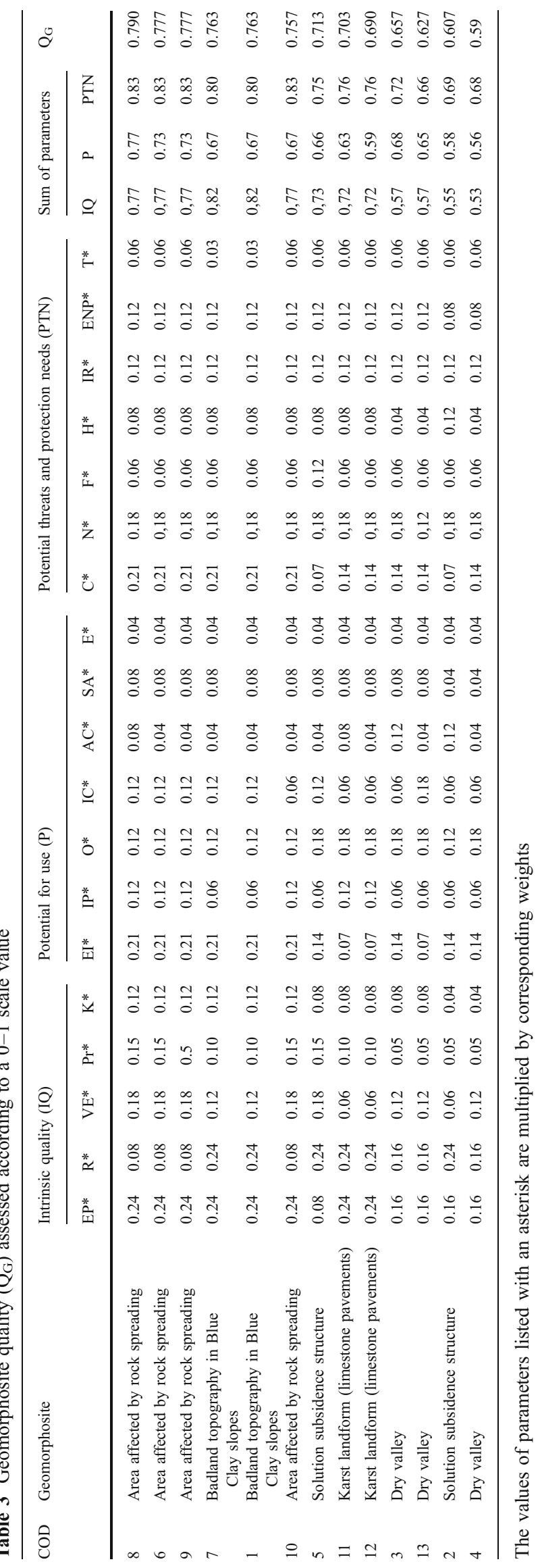


(2005) carried out specifically for territorial planning, environmental impact assessment procedures and for a geomorphosite inventory of the Modena Province plain (Emilia-Romagna Region, Italy). This methodology is easy to apply and is best suited if used by experienced Earth scientists who have either been working in the region or have access to sufficient detailed geological and geomorphological maps and literature. The methodology is quantitative, but a series of qualitative guidelines have been elaborated in order to give support to the attribution of values.

In particular, the scientific quality of a geomorphosite is evaluated by means of several parameters, a number of which are directly linked to the scientific identity of the assets, whereas others are only indirectly related to it. These parameters are Scientific value (S), Educational value (D), Rarity (R), Degree of conservation (C), Exposure (E) and Added value $(\mathrm{Z})$. Various criteria are applied to weight the Scientific value (S), such as number and quality of the scientific publications on a particular geomorphosite; whether there are research programmes in progress at a specific site; how representative a geomorphosite can be for the evolutionary reconstruction of the territory; whether a geomorphosite is important for the history of geomorphology in general. The Educational value (D) refers to representativeness of a particular form or process for educational purpose. Questions to be answered are: (1) Is a given geomorphosite quoted in educational textbooks or included in a tourist/educational itinerary? (2) What is the educational level of such itinerary? (3) Is the geomorphosite also known outside the scientific community? Rarity (R) is related to the quantity of similar geomorphosites present in the stretch of territory considered, and it depends on the size of the study area. The Degree of conservation (C) refers to the level of intactness, which depends on both natural and anthropogenic factors. Exposure (E) refers to the visual impact and the accessibility to the sites. The Added value (Z) is linked to the importance that a geomorphosite assumes owing to non-geomorphological aspects which increase its overall value (e.g. tourism, ecological characteristics, cultural aspects etc.). The aim of this parameter is to highlight possible links that may exist between geomorphology and other natural and cultural aspects that can provide a high recreational function.

Scientific Quality (Q) is calculated by means of the following expression:

$\mathrm{Q}=\mathrm{sS}+\mathrm{dD}+\mathrm{rR}+\mathrm{cC}+\mathrm{eE}+\mathrm{zZ}$

where $\mathrm{S}, \mathrm{D}, \mathrm{R}, \mathrm{C}, \mathrm{E}, \mathrm{Z}$ are the values and $\mathrm{s}, \mathrm{d}, \mathrm{r}, \mathrm{c}, \mathrm{e}, \mathrm{z}$ are the related weights.

For the study area, the weights assigned to the parameters, according to the main aim of this research, range from zero $(0)$ to very high (1). Of course the most important parameter is the scientific value of the site, with the assigned weight for this parameter having the highest score (1). The scientific value, together with rareness and degree of conservation, is directly linked to the scientific identity of the asset and represents its intrinsic quality. Nevertheless, according to the need to select sites of geomorphological interest useful for educational and tourism purposes, high values have also been assigned to the other parameters. In order to select geomorphosites with a high recreational function, criteria such as educational value, exposure, both in terms of accessibility and visibility, and evidence of importance in other contexts (e.g. biological, ecological, archaeological, historical) are felt to be the most relevant as they clearly reflect tourism needs. Indeed, the weight of 0.75 has been assigned to those criteria.

The $\mathrm{Q}$ value thus obtained is then normalised in order to obtain values of 0 to 1 , according to the formula: $\mathrm{Q}=\mathrm{Qn} / \mathrm{Qmax}$ where: $\mathrm{Qn}=$ Scientific Quality of a geomorphosite and $\mathrm{Qmax}=$ maximum value that a geomorphosite can express.

The results of numerical assessment and ranking of geomorphosites are presented in Table 4.

This method also shows that rock spreading (ID 8, 9, 10) is the most valuable type of geomorphosite in the Park, being the strongest in terms of scientific and educational value and also scoring highest in degree of conservation and exposure.

\section{Discussion of Results}

The two methods applied for the assessment of geomorphosites in the study area are each characterised by their own unique peculiarities, although they do ultimately provide comparable results.

The first method adopted is quantitative, being based on parameters that can be numerically measured by an expert and do not depend on the expert's perception (e.g. rarity, degree of knowledge, accessibility etc.). For "measuring" these parameters, a series of indicators, with a three-term (1-3) ranking has been established and used (Bruschi and Cendrero 2005). The number of parameters to be taken into account and the amount of data to be collected are, however, relatively high, which makes the procedure rather complex. It should be emphasised that this quantitative method, due to its intrinsic characteristics, foresees a standard procedure independent of the physical characteristics of the area and the aim of the assessment.

The second method used is semi-quantitative and is based on the use of qualitative parameters. The number of parameters is lower than in the first method, thus making the assessment simpler and easier to carry out. This method, however, implies a higher component of subjectivity and, 
Table 4 Geomorphosites quality assessment

\begin{tabular}{|c|c|c|c|c|c|c|c|c|c|c|c|c|c|c|c|}
\hline ID & Geomorphosites & S & $\mathrm{D}$ & $\mathrm{R}$ & $\mathrm{C}$ & $\mathrm{E}$ & $\mathrm{Z}$ & $\mathrm{S}^{*}$ & $\mathrm{D}^{*}$ & $\mathrm{R}^{*}$ & $\mathrm{C}^{*}$ & $\mathrm{E}^{*}$ & $Z^{*}$ & Q & $\mathrm{Q}_{\mathrm{n}}$ \\
\hline 1 & $\begin{array}{l}\text { Badland topography } \\
\text { in Blue Clay slopes }\end{array}$ & 1 & 0.75 & 0.5 & 1 & 0.75 & 0.5 & 1.00 & 0.56 & 0.12 & 0.75 & 0.56 & 0.37 & 3.36 & 0.85 \\
\hline 2 & Solution subsidence structure & 1 & $0 ., 75$ & 0.75 & 0.5 & 0.5 & 0.5 & 1.00 & 0.56 & 0.01 & 0.37 & 0.37 & 0.37 & 2.68 & 0.68 \\
\hline 3 & Dry valley & 0.5 & 0.75 & 0.5 & 0.5 & 0.75 & 0.5 & 0.50 & 0.56 & 0.12 & 0.37 & 0.56 & 0.37 & 2.48 & 0.63 \\
\hline 4 & Dry valley & 0.5 & 0.75 & 0.5 & 0.5 & 0.75 & 0.5 & 0.50 & 0.56 & 0.12 & 0.37 & 0.56 & 0.37 & 2.48 & 0.63 \\
\hline 5 & Solution subsidence structure & 1 & 1 & 0.75 & 1 & 1 & 0.5 & 1.00 & 0.75 & 0.19 & 0.75 & 0.75 & 0.37 & 3.81 & 0.96 \\
\hline 6 & $\begin{array}{l}\text { Area affected by rock } \\
\text { spreading }\end{array}$ & 1 & 1 & 0.5 & 1 & 0.75 & 0.75 & 1.00 & 0.75 & 0.12 & 0.75 & 0.56 & 0.56 & 3.74 & 0.95 \\
\hline 7 & $\begin{array}{l}\text { Badland topography } \\
\text { in Blue Clay slopes }\end{array}$ & 1 & 1 & 0.5 & 1 & 0.75 & 0.75 & 1.00 & 0.75 & 0.12 & 0.75 & 0.56 & 0.56 & 3.74 & 0.95 \\
\hline 8 & $\begin{array}{l}\text { Area affected by rock } \\
\text { spreading }\end{array}$ & 1 & 1 & 0.5 & 1 & 1 & 0.75 & 1.00 & 0.75 & 0.12 & 0.75 & 0.75 & 0.56 & 3.93 & 1.00 \\
\hline 9 & $\begin{array}{l}\text { Area affected by rock } \\
\text { spreading }\end{array}$ & 1 & 1 & 0.5 & 1 & 1 & 0.75 & 1.00 & 0.75 & 0.12 & 0.75 & 0.75 & 0.56 & 3.93 & 1.00 \\
\hline 10 & $\begin{array}{l}\text { Area affected by rock } \\
\text { spreading }\end{array}$ & 1 & 1 & 0.5 & 1 & 1 & 0.75 & 1.00 & 0.75 & 0.12 & 0.75 & 0.75 & 0.56 & 3.93 & 1.00 \\
\hline 11 & $\begin{array}{l}\text { Karst landform (limestone } \\
\text { pavements) }\end{array}$ & 1 & 0.75 & 0.5 & 1 & 1 & 0.75 & 1.00 & 0.56 & 0.12 & 0.75 & 0.75 & 0.56 & 3.74 & 0.95 \\
\hline 12 & $\begin{array}{l}\text { Karst landform (limestone } \\
\text { pavements) }\end{array}$ & 1 & 0.75 & 0.5 & 1 & 1 & 0.75 & 1.00 & 0.56 & 0.12 & 0.75 & 0.75 & 0.56 & 3.74 & 0.95 \\
\hline 13 & Dry valley & 0.5 & 0.5 & 0.5 & 0.75 & 0.5 & 0.5 & 0.50 & 0.37 & 0.12 & 0.56 & 0.37 & 0.37 & 2.29 & 0.58 \\
\hline
\end{tabular}

The columns listed with an asterisk are multiplied by corresponding weights

therefore, expert knowledge becomes very important. Moreover, the allocation of values and weights to the parameters used largely depends on the experience and sensitivity of the expert involved in assessment as well as on the purpose of the research. It should be noted that the aim of this assessment procedure was to promote and enhance the rich geoheritage of the study area. Therefore, in applying this semi-quantitative methodology, particular importance was given not only to the scientific quality of the geomorphosites but also to other parameters, such as cultural, aesthetic and ecological ones. In addition, parameters which clearly reflect tourism needs, such as accessibility, visibility and educational criteria, have been considered.

In order to identify the differences between such standings and to determine the reliability of the methodologies, we have compared the results of the two methodological approaches (Table 5). The degree of coincidence between two rankings is quite good, as more than $84 \%$ of sites show similar values. A Spearman correlation coefficient (Freund et al. 2000) has been applied, which provides the degree of

Table 5 Comparison between results obtained from the two quantitative assessments $($ Spearman coefficient $=0.84$ )

\begin{tabular}{lllll}
\hline $\mathrm{Q}_{\mathrm{G}}(0-1)$ & Quantitative parametric method & ID & ID & Semi-quantitative method \\
\hline 0.790 & Area affected by rock spreading & 8 & 8 & Area affected by rock spreading \\
0.777 & Area affected by rock spreading & 6 & 9 & Area affected by rock spreading \\
0.777 & Area affected by rock spreading & 9 & 10 & Area affected by rock spreading \\
0.763 & Badland topography in Blue Clay slopes & 7 & 5 & Solution subsidence structure \\
0.763 & Badland topography in Blue Clay slopes & 1 & 6 & Area affected by rock spreading \\
0.757 & Area affected by rock spreading & 10 & 7 & Badland topography in Blue Clay slopes \\
0.713 & Solution subsidence structure & 5 & 11 & Karst landform (limestone pavements) \\
0.703 & Karst landform & 11 & 12 & Karst landform (limestone pavements) \\
0.690 & Karst landform & 12 & 1 & Badland topography in Blue Clay slopes \\
0.657 & Dry valley & 3 & 2 & Solution subsidence structure \\
0.627 & Dry valley & 13 & 3 & Dry valley \\
0.607 & Solution subsidence structure & 2 & 4 & Dry valley \\
0.590 & Dry valley & 4 & 13 & Dry valley \\
\hline
\end{tabular}


correlation or similitude between two sets of ranks. It can vary between -1 (negative correlation) and 1 (positive correlation); values close to zero indicate dissimilitude between individuals. In this case, the Spearman coefficient is 0.84 and indicates a high positive correlation.

It is evident that in both classifications those sites with the highest values are sites of the same category, namely, areas affected by rock spreading. The significance of these results lies in the possibility to identify the most and least valuable sites with both methods.

\section{Conclusions and Perspectives}

The quantitative method was previously tested in northern Spain within the framework of a selection and assessment procedure of geomorphosites in a coastal area (Bruschi and Cendrero 2009), while the semi-quantitative one has been set up and tested within a procedure of environmental impact assessment carried out in a plain area of northern Italy (Coratza and Giusti 2005). The results achieved with this study confirm that the proposed methodologies can be applied to different geomorphological environments. Furthermore, the semi-quantitative method, with appropriate changes in the weights assigned to the various parameters, can also be applied for different purposes, outside the scope of its original format.

It is possible to conclude that both methodologies can provide a useful ranking of geomorphosites. Despite the differences between the applied criteria, our results show a high degree of correspondence, especially with respect to the assessment of the highest and lowest valued sites.

Geomorphosites have the potential to be acknowledged as natural and tourist resources with interesting economic benefits, especially if located in protected areas (Zouros 2007). The proposed methodologies, based on the integration on both scientific and socio-cultural issues related to the geological objects, could support the selection of geomorphosites for promotional purposes and, in particular, for their inclusion in the existing itineraries of the Park. The results obtained indicate that the geomorphosites with the highest value represent tourist attractions that also satisfy the criteria of scientific and educational value as well as those of aesthetic appeal and potential for use.

It is assumed that this process of classification and assessment of the geomorphological features of the IlMajjistral Nature and History Park will contribute towards the improved protection and management of geological sites. The results can provide the basic knowledge needed for the development of a sustainable and responsible tourism industry, favouring a good understanding and comprehension of the landscape and its evolution. In fact, the market for naturalistic and cultural tourism beyond the aesthetic aspect of a landscape requires a better understanding of the geological and geomorphological environment, as well as knowledge of its genesis and evolution (Reynard et al. 2003; Dowling and Newsome 2005; Pelfini et al. 2009). The selection of sites satisfying criteria of scientific and educational value, but also those of aesthetic appeal and potential for use, can facilitate the development of this new kind of tourism.

Based on these assumptions and on the identification of the selected sites, geological-cultural itineraries will be identified that can be used and enjoyed by the widest public possible. Moreover, when a given geomorphosite acquires a tourism value, it is necessary to assess the possible natural hazard processes which might threaten the safety of visitors (Soldati et al. 2008b). In particular, fast-occurring processes might directly involve tourists in proximity of the site of interest or along access roads and footpaths. Examination of the chronicles of accidents occurring along the coast reveals that landslides, and in particular rock falls, are processes which should be taken into account more than any others. In order to develop a safe and sustainable geotourism industry, consideration must not only be given to those sites with the highest value, but also to the rapid events that may affect a trail network, both close to a trail and across a much vaster area (Pelfini et al. 2009).

Moreover, the creation of nature trails is accompanied by negative environmental impacts on geomorphosites. In this context, in the second phase of the research it will be necessary to identify with as much detail as possible those areas more subject to the onset of hazard disarray processes and the possible impact of tourism on geomorphosites (Panizza 2003; Pelfini et al. 2009).

The results of this research provide the necessary basic knowledge for the possible enhancement of the geomorphological features of the area and for the promotion of tourist activities at the Il-Majjistral Nature and History Park, which should be carried out by public institutions responsible for the protection of the Maltese territory.

\section{References}

Alexander D (1988) A review of the physical geography of Malta and its significance for tectonic geomorphology. Quatern Sci Rev 7:41-53

Barba FJ, Remondo J, Rivas V (1997) Propuesta de un procedimiento para armonizar la valoración de elementos del patrimonio geológico. Zubia 15:11-20

Bruschi VM (2007) Development of a methodology for the characterization, assessment and management of geodiversity resources. $\mathrm{PhD}$ thesis. Universidad de Cantabria, Santander

Bruschi VM, Cendrero A (2005) Geosite evaluation; can we measure intangible values? II Quaternario 18(1):293-306

Bruschi VM, Cendrero A (2009) Direct and parametric methods for assessment of geosites and geomorphosites. In: Reynard E, 
Coratza P, Regolini-Bissig G (eds) Geomorphosites. Pfeil, Munich, pp 73-88

Bruschi VM, Cendrero A, Cuesta Albertos JA (2011) A statistical approach to the validation and optimisation of geoheritage assessment procedures. Geoheritage, this volume

Coratza P, Giusti C (2005) Methodological proposal for the assessment of the scientific quality of geomorphosites. II Quaternario 18(1):307-313

Cyffka B, Bock M (2008) Degradation of field terraces in the Maltese Islands - reasons, processes, and effects. Geogr Fis Dinam Quat $31: 119-128$

Dowling R, Newsome D (2005) Geotourism. Elsevier, Oxford

Fines KD (1968) Landscape evaluation: a research project in east Sussex. Reg Stud 2:41-55

Freund JE, Miller M, Miller I (2000) Estadística matemática con aplicaciones. Pearson Educación, Mexico City

House MR, Dunham KC, Wrigglesworth JC (1961) Geology and structure of the Maltese Islands. In: Bowen-Jones H, Dewdney JC, Fisher WB (eds) Malta. Background for development. Durham University Press, Durham, pp 62-78

Leopold LB (1969) Landscape aesthetics. Nat Hist 10:35-46

Linton DL (1968) The assessment of scenery as a natural resource. Scott Geogr Mag 84:218-238

Magri O (2009) Investigation of landslides along the north-west coast of Malta and related hazard issue. $\mathrm{PhD}$ thesis. University of Modena and Reggio Emilia, Modena

Magri O, Mantovani M, Pasuto A, Soldati M (2007) Monitoring the state of activity of lateral spreading phenomena along the north-west coast of Malta using the GPS technique. Analele Universitatii Din Oradea 17:5-10

Mottershead D, Pearson A, Schaefer M (2008) The curt ruts of Malta: an applied geomorphology approach. Antiquity 82:1065-1079

Murray J (1890) The Maltese Island with special reference to their geological structure. Scot Geogr Mag 6:449-489

Oil Exploitation Directorate (1993) Geological map of the Maltese Islands. Sheets 1 and 2, scale 1: 25,000. Oil Exploitation Directorate, Office of the Prime Minister, Malta

Panizza M (2001) Geomorphosites: concepts, methods and examples of geomorphological survey. Chin Sci Bull 46:4-6

Panizza M (2003) Géomorphologie et tourisme dans un paysage culturel intégré. In: Reynard E, Holzmann C, Guex D, Summermatter N (eds) Géomorphologie et tourisme. Travaux et recherches, vol 24. Institut de Géographie, Lausanne, pp 11-18

Panizza M, Piacente S (1993) Geomorphological assets evaluation. Z Geomorph, N.F. 87:13-18

Paskoff R (1985) Malta. In: Bird EC, Schwartz ML (eds) The world's coastlines. Van Nostrand Reinhold Company, New York, pp 431437

Paskoff R, Sanlaville P (1978) Observations géomorphologiques sur les côtes de l'archipel maltais. Zr Geomorph, N.F. 22:310-328

Pedley HM, House MR, Waugh B (1976) The geology of Malta and Gozo. Proc Geol Assoc 87:325-341
Pedley HM, House MR, Waugh B (1978) The geology of the Pelagian Block: the Maltese Islands. In: Nairn AEM, Kanes WH, Stehli FG (eds) The ocean basins and margins, vol 4B: the Western Mediterranean. Plenum, New York, pp 417-433

Pedley HM, Hughes Clarke M, Galea P (2002) Limestone isles in a crystal sea. The geology of the Maltese Islands. PEG Ltd, Malta

Pelfini M, Brandolini P, Carton A, Piccazzo M (2009) Geotourist trail: a geomorphological risk-impact analysis. In: Reynard E, Coratza P, Regolini-Bissig G (eds) Geomorphosites. Pfeil, Munich, pp 131143

Pena dos Reis R, Henriques MH (2009) Approaching an integrated qualification and evaluation system for geological heritage. Geoheritage 1:1-10

Pereira P, Pereira D, Caetano Alves MI (2007) Geomorphosite assessment in Montesinho Natural Park (Portugal). Geogr Helv 62(3): $159-168$

Pralong JP (2005) A method for assessing tourist potential and use of geomorphological sites. Géomorphol Relief Processus Environ 3:189-196

Reynard E (2004) Geosites. In: Goudie AS (ed) Encyclopedia of geomorphology. London, Routledge, p 440

Reynard E (2009) The assessment of geomorphosites. In: Reynard E, Coratza P, Regolini-Bissig G (eds) Geomorphosites. Pfeil, Munich, pp 63-71

Reynard E, Holzmann C, Guex D, Summermatter N (eds) (2003) Géomorphologie et tourisme. Travaux et recherches, vol. 24 Institut de Géographie, Lausanne

Reynard E, Fontana G, Kozlik L, Scapozza C (2007) A method for assessing « scientific » and « additional values » of geomorphosites. Geogr Helv 62(3):148-158

Rivas V, Rix K, Frances E, Cendrero A, Brunsden D (1997) Geomorphological indicators for environmental impact assessment: consumable and non consumable geomorphological resources. Geomorphology 18(3-4):169-182

Serrano E, Gonzalez-Trueba JJ (2005) Assessment of geomorphosites in natural protected areas: the Pico de Europa National Park (Spain). Géomorphologie: relief, processus, environnement 3:197-208

Soldati M, Buhagiar S, Coratza P, Pasuto A, Schembri JA (2008a) Integration of the geomorphological environment and cultural heritage: a key issue for present and future times. Geogr Fis Din Quat 31:95-96

Soldati M, Buhagiar S, Coratza P, Pasuto A, Schembri JA (eds) (2008b) Integration of the geomorphological environment and cultural heritage for tourist promotion and hazard prevention. Geogr Fis Dinam Quat 31:93-247

Trumbic I (2004) Tourism carrying capacity in Mediterranean coastal tourist destinations. In: Coccossis H, Mexa A (eds) The challenge of carrying capacity assessment for tourism. Ashgate, London, pp 135150

Zouros NC (2007) Geomorphosite assessment and management in protected areas of Greece. Case study of the Lesvos island - coastal geomorphosites. Geogr Helv 62(3):169-180 